\section{ERADICATION OF TUBERCULOSIS 22\% IN CATTLE}

T $N$ the course of the last half-century, much has been written of the danger to the human population of the existence of tuberculosis in cattle. There have been strond demands for the elimination of the disease from cattle in Britain, and inevitably opposif $\mathrm{n}$ " to this policy has been roused, on the ground of the magnitude of the task from the economic aspect; the danger of damaging the milk supply of the nation because of the large proportion of milch cows that are tuberculous ; the desirability of maintaining infection with tuberculosis in order that the milk of the nation may be infected, so that those consuming it may acquire immunity and withstand the ordinary risks of infection from contact with people suffering from the disease ; from a belief that pasteurization destroys a food factor not easily replaceable, and essential for those who depend largely or entirely on a milk diet; and by some because of a mystical belief that animals should be maintained according to what are spoken of vaguely as 'natural' methods.

A great deal of factual information is now available, and experience in other countries strengthens the case of those who favour action to remove a serious source of ill-health in the most important class of livestock in Britain. To-day it can be asserted with confidence that the important agricultural interests are to the fore in the demand for means to get rid of the disease. On many of the questions which were controversial only a few years ago, there is now general agreement.

The history of efforts to control the disease in cattle in all countries is that individual voluntary effort fails to yield results of any considerable value. T'o attain results which are worth while, operations have to be carried out through the agency of wellorganised government departments, supported by certain powers conferred by legislative action, with the co-operation of the industries concerned and under conditions that onable financial aid on a suitable scale to be given to compensate for the special measures required from the owner, until success has been achieved. A primary factor in the organisation for ridding cattle of the disease is the possession of a sufficiently reliable and convenient means of detecting the affected animals. This is provided by the tuberculin test. There are, however, differences of opinion about the most suitable type of tuberculin and the manner in which it should be used.

In the United States of America, an intense nation-wide campaign was carried out by combined F'ederal and State veterinary departments from 1917, when it was considered that 6-8 per cent of all American cattle were infected, until 1940, when in every county of every State less than one half of one per cent of the cattle were reactors to the tuberculin test and, incidentally, not more than one half of those reactors in 1940 were actually affected with tuberculosis. The tuberculin used in this campaign was prepared from a culture of tubercle bacilli grown on a special nutrient medium consisting entirely of known chemical prcducts and free from proteins. The resultant growth was then concentrated by heating. A more refined type of tuberculin is now available. It is grown similarly on a defined chemical, protein-free culture medium, but it is concentrated chemically, to separate the tuberculin protein, known as 'purified protein derivative' (P.P.D.), from the other constituents of the final growth. The tuberculin prepared officially for use on animals in Great Britain is P.P.D.

There are different ways of using tuberculin. The intradermal test is conceded to be eminently satisfactory in cattle. In the United States, a dose of tuberculin is injected intradermally into a subcaudal fold; there are two natural folds of skin in cattle at the ventral surface of the root of the tail, and the uninjected fold serves as a control. In Great Britain a 'double intradermal' test has been used for the last twenty years or so. A dose of tuberculin is injected intradermally in the skin at one side of the neck, and forty-eight hours later a second dose of tuberculin is injected into the same site.

At the recent congress of the Royal Sanitary Institute at Blackpool, at a meeting of the Section of Veterinary Hygiene, Mr. John Francis, of Imperial Chemical Industries, Ltd. (Biological Laboratories), discussed the tuberculin test in detail and also the control of tuberculosis in cattle, with special reference to conditions in Great Britain.

Prof. T. Dalling, director of the Veterinary Laboratory, Ministry of Agriculture, described work on the disease in progress in Great Britain. $\mathrm{He}$ emphasized that, in addition to the great danger to human beings from tuberculosis in cattle, the economic loss sustained by the farming industry and by the State, on account of the extent of the disease in our cattle, is also very important. There is clear evidence that herds free from the disease have a very much higher standard of health than infected herds. When young stock in affected herds are kept apart from the adult cattle, and are not given infected milk, the tuberculosis-rate in them is low. Incidentally, cattle can acquire the disease from contact with infected human beings.

Tests of the usefulness of the vaccination of cattle against the disease have been in progress for some years. Results of some value have been obtained, and it is possible that in certain circumstances vaccination may play a part in control operations. For some years farmers have been encouraged to eliminate the disease through the government Attested Herd and Tuberculin Tested Herd schemes, and a good deal of progress has been made, in that a large number of herds are now so dealt with.

Prof. Dalling explained that investigations of the value of the different types of intradermal tuberculin tests are in progress, and that if a simpler test than the one hitherto used in Great Britain is found to be satisfactory, it will be given consideration by those responsible for policy.

The following resolution was passed at the meeting : "That this section is of the opinion that the Government, in its post-war plans for increasing the efficiency of agriculture and so improving public health, should give high priority to the eradication of bovine tuberculosis".

Closely bound up with the tubereulosis problem, but concerned also with other diseases that affect mankind, is the general question of a safe milk supply. Recent developments are discussed in an article in the Lancet of March 2. Among the matters referred to are the pasteurization controversy; the monetary value of the losses due to tuberculosis in cattle ( $£ 20-£ 30$ million a year); the marking of cattle that are reactors to the tuberculin test; the 
inoculation of calves against bovine brucellosis (contagious abortion); financial assistance required by farmers to help them to free their herds from tuberculosis ; the provision of a free State veterinary service; the establishment of a system of eradicating tuberculosis by producing disease-free areas, which would be gradually extended; the provision of a State abattoir service under veterinary supervision, to ensure that the meat supply is sound and, incidentally, to serve as a guide to the incidence of the important diseases of cattle; the need for adequate water supplies on farms and, on a great many farms, for improved buildings.

The article deals with many aspects of the subject and shows in what directions developments are required; and it is to be hoped that, before long, it will be possible to embark on a new stage of the campaign against disease in dairy cattle. What many would like to see would be the first stages of an 'area plan'.

\section{6}

\section{THE SIGNIFICANCE OF SCIENCE FOR ANDIA}

$\mathrm{T}$ HE annual agress by the president to the Royal Asiafe Society of Bengal is often of much interest to men of science, and that delivered by Prof. M N. Stha last February is no exception. The earlier $p$ p f $f$ the address is directed, as is customary, to the ayirs of the Society. Prof. Saha mentions the nelebrations in January of this year of the bignitenary of the birth of Sir William Jones, the founder of the Asiatick Society in 1784. He records with pleasure the presence at this celebration of delegates from Iran and Afghanistan, and of the writer of this note as the representative of the Royal Society of London. There is no doubt that much good results from such visits and personal contacts, and that scientific workers in their intercourse with those of other countries do much to promote the friendship that is indifferent to, and often cuts across, political trends. When international congresses in science, and other learned activities of man, can be resumed without let and hindrance due to considera. tions of finance, rationing and polities, the world will be further on the path to peace than appears at present to be the case.

Prof. Saha directs attention, as has often been done before, to the magnificent collection of Sanskrit, Persian and Arabic manuscripts, numbering some fifty thousand, held in trust by the Society for the public. He records the grant by the Government of Bengal of four research fellowships for Sanskrit and Islamic studies and for research in epigraphy and numismatics. A need of the Society that grows more pressing yearly is for new and more commodious premises to replace the beautiful but now structurally unsound building (137 years old) in which the Society is housed at 1 Park Street, Calcutta. Application for financial aid has been made both to the Government of India and to the Government of Bengal. Lord Wavell has himself shown sympathy in this matter.

The main portion of Prof. Saha's address is of unusual interest, because during his period as president he was also a member of the Indian Scientific Mission that visited the United. Kingdom and the United States during 1944-45. Later, in 1945, Saha visited the U.S.S.R. as the Indian delegate on the occasion of the 220th anniversary celebrations of the Academy of Sciences of the U.S.S.R. These visits were all made by air. In his address, Prof. Saha is able to discuss in turn scientific activities in Great Britain, the United States and the U.S.S.R., and he speaks with admiration of the work done in each of these three countries during the War. With reference to Great Britain he writes : "Science has saved Britain and led to victory". He summarizes the views of Sir John Anderson and Prof. A. V. Hill that the progress of science and of its application to publie welfare depends on the four M's : "Men, money, material, and machinery or organisation", and thinks that Britain will never again allow science to be neglected in her home country. He continues: "Can this be said of India? As far as my knowledge goes, neither Prof. Hill's valuable report, nor the resolution of the National Institute of Sciences that one per cent of the central and provincial budget should be set aside for scientific research, nor the measures of taxation relief in the case of endowments for scientific researches proposed by no less a person than the late Finance Member Sir Jeremy Raisman himself, has yet been considered seriously by the Government of India."

Among many interesting remairks on the development of the United States, Prof. Saha draws a lesson from California: "The people must have the genius to develop the resources with which Nature has bountifully endowed almost every major country. This was nowhere more apparent to us than in the State of California, which, with its green orchards, fertile fields and clear sky reminded us strongly of our own Bengal. We thought that the rainfall must have been as heavy as in Bengal otherwise the country could not be so green and productive. On enquiry we found that the average precipitation was no larger than 16 inches, almost the same as we find in the desert parts of the southern Punjab. Whence comes the life-giving water which nourishes the fields of California?"

The answer is that California is irrigated by water brought some three hundred miles from the Colorado River through an aqueduct. This enterprise and the harnessing of other rivers in America for the development of power leads Prof. Saha to eulogize President Roosevelt for his part in promoting the New Deal in America, and in overcoming the reluctance of the separate States to grant facilities for such projects as the Tennessee Valley Authority.

On his journey to the U.S.S.R., Prof. Saha visited Bahrein and crossed Arabia by air, and this led him to mention the great oil discoveries that have been made in Arabia and the U.S.S.R. as a result of geophysical research, and the necessity of employing such methods in India (the Burmah Oil Co. Ltd. has, of course, been doing this for years). He also records how in the U.S.S.R. the Academy of Sciences has, during the last twenty-five years, been invested with wide administrative powers, with a budget equivalent to nearly 10 crores of rupees $(£ 7,500,000)$, managing seventy-six research institutions and a number of scientific commissions : in fact, the Academy is the mainspring of scientific life in the U.S.S.R.

Prof. Saha summarizes his conclusions as follows: "Old national boundaries have vanished, and the new age will be one of 'Super States'. Little States cannot survive either politically or economically. The U.S.A. has achieved this position earlier than all other nations because : (a) one hundred and seventy years ago it won the fight to work out its own destinv : 